\title{
Dziedzictwo przodków i tożsamość narodowa - współczesna szamanka (baqsï) w filmie kazachskim i badaniach etnologicznych
}

\section{Abstract}

\section{Ancestral Heritage and National Identity: About a Contemporary Shaman (baqsi) in a Kazakh Film and in Ethnological Research}

This paper deals with problems of nation-building and constructing national identities in the newly independent Central Asian countries, focusing on Kazakhstan and the personage of a female shaman - the main character of the film Baksy, as an incarnation of Kazakh national ideals and values. This depiction is confronted with a presentation of the real baqsï living in the village in the south of Kazakhstan who was a prototype of Ayday Apa from the film. Based on my research conducted in Almaty between 1995-2000, I compare these characters with urban shamans and other spiritual healers, showing their hybridised ideas and healing practices. I argue that since they have to adapt to the demands of urban, multi-ethnic clientele, they do not present themselves as carriers of the ancestral heritage, as Kazakh village healers often do. However, it is the shaman of the latter kind who was presented in the film, because she could be used as an epitomisation of presumed national Kazakh values such as commitment to the ancestral land and deep spirituality. The case discussed in the paper is only one example of the numerous efforts to boost national self-identity and pride, observed in various cultural, social and scientific activities in contemporary Kazakhstan.

Keywords: ancestral heritage, national identity, shaman, film, Kazakhness, Kazakhstan, Central Asia. 
Do napisania tego artykułu skłoniły mnie wieloletnie zainteresowania metodami uzdrawiania duchowego, związanymi z szamanizmem oraz religią muzułmańską, które nie tylko nie odeszły w przeszłość, ale - w czasie moich badań - cieszyły się coraz większą popularnością w Azji Środkowej. Ponadto za niezwykle interesujące uważam procesy „budowania narodów”, tworzenia i wzmacniania tożsamości narodowej obserwowane w państwach tego regionu powstałych po rozpadzie Związku Radzieckiego. Wśród wykorzystywanych do tych celów odniesień do historii i kultury tytularnych narodów owych państw znalazło się miejsce także dla szamanizmu i innych form duchowości. Prezentuję i analizuję tutaj jedynie wybrane aspekty tych złożonych procesów. Koncentruję się na filmowym obrazie kazachskiej szamanki (baqsï), wskazując na przesłanie i kontekst specyficznego sposobu prezentowania tej postaci w filmie. Odnoszę to filmowe ujęcie do autentycznej postaci szamanki będącej pierwowzorem filmowej baqsï oraz porównuję z własnymi obserwacjami praktyk uzdrowicieli duchowych i wnioskami z wielu wywiadów i rozmów prowadzonych w trakcie badań etnograficznych w Kazachstanie w latach $1995-2000^{1}$.

\section{Tło - historia i kultura jako legitymizacja państwowości}

Wielkim wyzwaniem dla nowo powstałych na początku lat 90. XX wieku państw Azji Środkowej było legitymizowanie swej suwerenności państwowej, czego starano się dokonać, między innymi, przez pokazanie dawności i bogactwa kultury tytularnych grup etnicznych. Miało to duże znaczenie w państwach wieloetnicznych, a szczególnie w Kazachstanie, gdzie Kazachowie, w momencie proklamowania niepodległej Republiki Kazachstanu pod koniec roku 1991, stanowili mniej niż 50\% ogółu ludności². Misję „promowania” kazachskiej kultury jako fundamentu narodowej suwerenności Kazachów podjęli politycy, twórcy kultury i naukowcy - historycy, filozofowie, kulturoznawcy, a także niektórzy etnografowie. Zaczęły powstawać książki o aspiracjach naukowych, dzieła sztuki, spektakle teatralne, filmy, w których przedstawia się chwalebne epizody z dziejów narodu, głębię „filozofii koczowników” i wartości ich kultury, eksponując zwłaszcza ścisłe związki z naturą, wyidealizowany, pełen harmonii tryb życia, poszanowanie dla

${ }^{1}$ Moje długotrwałe badania terenowe dotyczyły szeroko rozumianej medycyny komplementarnej w Kazachstanie, w jej różnorodnych przejawach, wraz ze złożonymi relacjami z biomedycyną. Uwzględniłam również szeroki kontekst przemian polityczno-gospodarczych i społecznych zachodzących w tym nowo powstałym państwie. Badania prowadziłam przede wszystkim w Ałmaty (wcześniej znanej jako Ałma Ata), uprzedniej stolicy kraju, w 1997 r. przeniesionej do Astany. Ich rezultatem, prócz kilku artykułów, była książka Medycyna komplementarna w Kazachstanie. Siła tradycji i presja globalizacji (2006).

2 Według danych z 2016 r. Kazachowie stanowią obecnie 63,1\% populacji, przed Rosjanami (23,7\%), http://www.indexmundi.com/kazakhstan/demographics_profile.html (dostęp 24.05.2017). 
przodków i ziemi, po której wędrowali. Wiele pisze się też o przedislamskiej religii Kazachów zwanej tengryzmem czy tengrianizmem (od boga Nieba Tengri), którą czasem stawia się nawet w pozycji równorzędnej w stosunku do islamu, podkreślając jej rzekomo monoteistyczny charakter (np. Akataj 2001: 79-86; zob. Laruelle 2007). Jednocześnie, choć rzadziej, część badaczy, polityków, działaczy życia społecznego i kulturalnego oraz dziennikarzy akcentuje znaczenie szamanizmu, postrzegając wierzenia i praktyki szamańskie jako autentyczną pradawną religię Kazachów, ściśle związaną z ich wartościami i sposobem życia. Ci „propagatorzy szamanizmu” odwołują się najczęściej do koncepcji znanego etnografa Čokana Valihanova, który prezentował owe wierzenia jako „religię natury” specyficzną dla koczowników³ .

Realizacja ważnego przesłania ideologicznego - tworzenia spójnego, przekonującego obrazu bogatej historii i kultury kazachskiej - wyrażanego explicite albo nieco bardziej ukrytego, doprowadziła do swoistego mitotwórstwa, przejawiającego się między innymi w tworzeniu wyidealizowanego wizerunku niektórych postaci historycznych (np. rozmaitych bohaterów - kaz. batïr, których imionami nazwano wiele ulic), doszukiwaniu się w odległej historii świadectw wczesnego powstania państwowości Kazachów (zob. Schatz 2000: 496) czy wspomnianym traktowaniu tengryzmu jako religii monoteistycznej. Zabiegi te niewątpliwie służyły i nadal służą „,budowaniu narodu”, który w istocie był dopiero w trakcie konsolidowania; budzeniu bądź wzmacnianiu poczucia dumy z bycia Kazachem. Jak pokazują badacze, tendencje do konstruowania i utwierdzania tożsamości narodowej na podstawie tego, co jest uważane za "tradycję”, są w Kazachstanie wciąż widoczne w różnych przejawach życia, poczynając od - na przykład - obchodów świąt, takich jak Nauryz, przypadający na wiosenne zrównanie dnia z nocą (Penkala-Gawęcka 2009), poprzez sztuki plastyczne (Kudaibergenova 2017), do muzyki popularnej w rodzaju „etnicznego rocka” (Rancier 2009) ${ }^{4}$. Ważne miejsce w promowaniu „kazachskości” (qazaqiyliq) zajmuje film, zarówno dokumentalny (zob. Laruelle 2015 - o serialu dokumentalnym Znaki. Stepnye legendy nadawanym w kazachstańskiej telewizji), jak i fabularny.

\section{Film współczesny a kazachska historia i tradycje}

Wskazane powyżej wątki możemy odnaleźć także w postsowieckiej kinematografii Republiki Kazachstanu. Do filmów niosących znaczące przesłanie ideolo-

${ }^{3}$ Čokan (Šokan) Valihanov (1835-1865) był pierwszym etnografem Kazachem. Duża część jego spuścizny dotyczy życia religijnego Kazachów (zob. Valihanov 1986).

${ }^{4}$ Megan Rancier słusznie podkreśla, że na te współczesne zjawiska wpłynęła w znacznym stopniu spuścizna sowieckiej polityki kulturalnej, usiłującej poprzez ostre zdefiniowanie granic etnicznych między poszczególnymi grupami ludności zamieszkującej Azję Środkową „zamienić je w odrębne «narody» i zachęcić do rozwijania własnych «narodowych» kultur" (Rancier 2009: 387). 
giczne należą na przykład nakręcone z rozmachem filmy historyczne w rodzaju Koczownika (2005) albo Mustafy Čokaya (2008), ale także bardziej kameralne obrazy, jak Aqsuat (1998), który życie w rodzimym aule przeciwstawia krytycznie prezentowanej tendencji do ucieczki do miasta, czy Myśliwy (2004) - interesujący film pokazujący trwałość tradycyjnego kazachskiego sposobu życia, utrzymywanego wbrew presji współczesności. Zwraca się tu uwagę na „etnograficzny szczegół”, pieczołowicie obrazując różne „tradycyjne” przejawy życia koczowniczego. O szczególnym znaczeniu takich filmów, budujących „poczucie narodowe”, piszą wprost kazachscy filmoznawcy.

Jednym z wielu składników kultury kazachskiej, które zostały uznane za świadectwo jej bogactwa i wartości, jest tradycyjna medycyna oraz uzdrawianie duchowe związane z szamanizmem i islamem. O oficjalnym poparciu dla tej części spuścizny przodków świadczy między innymi usankcjonowanie działalności uzdrowicieli, połączone z opracowaniem reguł ich weryfikacji i licencjonowania, oraz utworzenie w Ałma Acie już w 1990 roku, pod auspicjami Ministerstwa Zdrowia, Centrum Medycyny Ludowej (później nazwanego Republikańskim Centrum Medycyny Wschodniej i Współczesnej), a następnie jego filii w wielu miastach kraju. Największą jednostką w ramach Centrum był oddział kazachskiej medycyny ludowej, a wśród uzdrowicieli tam praktykujących można było spotkać także szamanów ${ }^{5}$. Znaczenie rodzimej medycyny tradycyjnej jako ważnej części "mądrości Wschodu” podkreślała często jedna z moich ałmatyńskich znajomych - uzdrowicielka i zarazem lekarka. W jednej ze swoich publikacji napisała ona, że poznawanie historii tego dziedzictwa „rozwija uczucie patriotyzmu, poprzez wykazanie wkładu narodu kazachskiego do cywilizacji światowej" (Habieva 2004: 235). Dodać trzeba, że mniemanie takie podzielało wielu innych reprezentantów nie tylko medycyny komplementarnej, ale także akademickiej.

Nie dziwi zatem, że i tego fragmentu kazachskiej tradycji nie pominięto w filmie, zarówno fabularnym, jak i dokumentalnym. Badacz religii współczesnych Kazachów zamieszkujących południe kraju, Bruce Privratsky (2001: 213), przytacza przykład dokumentalnego filmu telewizyjnego z 1997 roku, w którym zaprezentowaniu specyfiki kultury Kazachów służył między innymi wizerunek mułły z Turkiestanu oraz wróżki z Ałmaty, przepowiadającej przyszłość i leczącej $^{6}$. W drugiej połowie lat 90. oglądałam często podobne filmy i reklamowe spoty w telewizji - ze scenami z koczowniczego życia, obrazami wnętrza jurty i jej mieszkańców, a czasem także kazachskich uzdrowicieli. Co interesujące, posta-

${ }^{5}$ Więcej na ten temat: Penkala-Gawęcka (2006: 186-190). Należy pamiętać, że wprawdzie uzdrowiciele uznawani za szamanów są obecnie bardzo nieliczni, ale i dawniej byli oni rzadko spotykani - jako pośrednicy między swoją społecznością a światem pozaziemskim, obdarzeni nadzwyczajnymi zdolnościami (zob. Penkala-Gawęcka 2001).

${ }^{6}$ Chodzi o qumalaqšri - osoby (najczęściej kobiety) wróżące w tradycyjny sposób za pomocą 41 kamyków albo ziaren roślin, zwykle fasoli. Wierzy się, że to duchy przekazują wróżącym informacje o problemach pacjentów i sposobach poradzenia sobie z nimi (zob. Penkala-Gawęcka 2006: 156-157). 
ciom niektórych, szczególnie popularnych uzdrowicieli poświęcano specjalne filmy dokumentalne, które ich bohaterki czy bohaterowie wykorzystywali później do reklamy swojej działalności

\section{Filmowa baqsï jako uosobienie wartości kazachskiej kultury}

Współczesna kazachska szamanka, baqsï, stała się bohaterką filmu fabularnego. Analizując jej wizerunek w filmie pod tym właśnie tytułem, skupiam się na tym, w jaki sposób postać ta przekazuje tradycyjne wzorce i wartości kazachskiej kultury.

Film Baksy został zrealizowany w 2008 roku w koprodukcji kazachstańsko-francusko-niemieckiej, przy wsparciu Ministerstwa Kultury Kazachstanu, a reżyserowała go Guka Omarova ${ }^{8}$. Pierwowzorem bohaterki, szamanki Ayday, była popularna baqsï Bifatima, mieszkająca w wiosce Ungurtas nieodległej od Ałmaty, pokazana zresztą w pierwszych scenach filmu.

Przeanalizuję pokrótce elementy eksponowane w filmie, skupiając się na metodach uzdrawiania stosowanych przez szamankę i jej szczególnych zdolnościach oraz na ideach i wartościach, których jest nośnikiem.

\section{Metody leczenia, jasnowidzenie i inne zdolności szamanki}

Film jest nasycony szczegółami o charakterze etnograficznym. Praktyki uzdrowicielskie i wieszcze zdolności szamanki są prezentowane na ekranie z dbałością o zachowanie wiarygodności, pozwalają na odniesienia do wątków kulturowych znanych z literatury etnograficznej dotyczącej Kazachstanu i innych części Azji Środkowej. Opiszę kilka przykładów.

Kilka fragmentów filmu pokazuje uzdrawianie z użyciem krwi zwierzęcej. W jednej z pierwszych scen widać rytualne zabijanie zwierzęcia ofiarnego - czarnego barana - i oblewanie jego świeżą, ciepłą krwią chorej kobiety, która przyszła o kulach. Ayday Apa ${ }^{9}$ poleca kobiecie smarować krwią całe swoje ciało, wyznawać

7 Jako przykład może posłużyć Altyn Apa („Złota Matka”), którą spotkałam podczas I Konferencji Medycyny Ludowej i Tradycyjnej w Ałmaty w 1997 r. W swojej jurcie, specjalnie postawionej z tej okazji, przyjmowała gości poczęstunkiem i prezentowała wyprodukowane przez telewizję filmy o sobie.

${ }^{8}$ Piszący o filmie Omarovej krytycy filmowi sugerowali, że dwuznaczność tytułu jest zamierzona. Baksy pisane grażdanką (inaczej niż kazachskie baqsï - szaman, szamanka) oznacza bowiem w popularnym slangu amerykańskie dolary.

9 Apa-matka - to termin stosowany w odniesieniu do starszej, szczególnie poważanej kobiety. 
grzechy i wzywać imiona przodków, a następnie nakazuje jej wstać i iść, bez żadnego wsparcia. Tak też się dzieje. Natomiast w końcowej części filmu szamanka leczy chłopca, Hasana - który wskutek traumatycznego przeżycia stracił mowę i zdolność chodzenia - malując krwią wyobrażenie ptaka na jego plecach. Mówi przy tym: „Gdy krew wyschnie, dusza wróci do ciała”.

Rytualna ofiara zwierzęca wiąże się z różnymi uroczystościami życia rodzinnego środkowoazjatyckich muzułmanów, jest też ważnym elementem odwiedzin miejsc świętych. Również wykorzystanie krwi zwierzęcej, jako substancji „silnej”, oczyszczającej i ochronnej, a także organów zwierzęcych, szczególnie płuc, w uzdrawianiu oraz w innych obrzędach (na przykład weselnych), było i jest nadal częste. „Wyznanie grzechów i wzywanie imion przodków” nakazane chorej kobiecie przez Ayday należy natomiast rozumieć jako skłonienie jej do ich przebłagania, co jest traktowane jako warunek uzdrowienia. Oddawanie czci przodkom (ärwaq) ma bowiem szczególne znaczenie w życiu Kazachów. Zwracają się oni do swoich zmarłych przodków o pomoc w trudnych chwilach, otrzymują wskazówki w snach, zobowiązani są o nich pamiętać w modlitwach i składać ofiary. Zaniedbywanie, lekceważenie przodków, sprzeciwianie się ich woli może zostać surowo ukarane ${ }^{10}$.

Interesujące są sceny, które ukazują, jak szamanka leczy chorą dziewczynę, mażąc całe jej ciało warstwą gliny rozrobionej z mlekiem i wodą. Znaczenie ziemi w uzdrawianiu zostało zaakcentowane również w epizodach obrazujących sposób postępowania szamanki z ludźmi cierpiącymi na alkoholizm czy narkomanię. Leczenie z nałogów i złych skłonności polegało na przetrzymywaniu uzależnionych przez dłuższy czas w „klatce” - głębokiej jamie wykopanej w ziemi i zamkniętej od góry kratą. Małego Hasana natomiast, który przeżył silną traumę, Apa starała się uzdrowić, zawijając w skórę zwierzęcia (prawdopodobnie barana) i składając $\mathrm{w}$ jamie w ziemi.

Przekonanie o szczególnej mocy ziemi, reprezentowane w tych przekazach, jest podłożem często spotykanych w Azji Środkowej praktyk związanych z odwiedzaniem miejsc świętych (mazar). Osoby tam się udające pocierają nieraz twarz zebranym z ziemi pyłem bądź zabierają z sobą odrobinę ziemi (w tym wypadku dodatkowe znaczenie ma sakralny charakter miejsca, szczególnie jeśli jest to miejsce pochówku świętego).

Dodać trzeba, że ukazane w filmie owijanie chorego w świeżo zdjętą skórę zwierzęcia, najczęściej barana, szeroko występowało jako metoda leczenia w Azji Środkowej (Penkala-Gawęcka 1988: 147-148; 2006: 65-66) i gdzieniegdzie spotykane jest do dziś.

Często stosowanym przez filmową szamankę zabiegiem jest oblewanie i gwałtowne chlustanie wodą na przybywających do niej ludzi. To sposób duchowego

${ }^{10}$ Jak twierdzi Privratsky (2001: 119), kult przodków „określa Kazachów i ich akulturację do islamu". O obowiązkach wobec przodków i karach za ich niewypełnianie piszą również Paweł Jessa (2009: 61-64 i in.) i Penkala-Gawęcka (2006: 876). 
oczyszczania, który wiąże się z przekonaniem o uzdrawiającej sile wody. Warto tu nadmienić, że w wielu miejscach świętych odwiedzanych przez pielgrzymów w Azji Środkowej spotyka się źródła, z których wodę chorzy piją i oblewają się nią, by odzyskać zdrowie.

Ayday Apa stosuje nieraz brutalne, czasem wręcz drastyczne metody - bije tych, którzy są oporni, zwłaszcza owładniętych nałogami, używając przy tym nawet kija. Tradycyjny baqsï również bił pacjenta (zwykle biczem kamša), przeganiając złe duchy uważane za przyczynę choroby. To do dziś często występujący w Kazachstanie czy sąsiednim Kirgistanie sposób leczenia, choć zazwyczaj bicie jest już tylko symboliczne, zwłaszcza w wypadku praktyk uzdrowicieli miejskich.

Zdolność jasnowidzenia szamanki została kilkakrotnie wyeksponowana w filmie. Ayday pomaga odnaleźć krowę ukradzioną parze staruszków - Kazachów, dla których sprzedaż mleka była podstawowym źródłem utrzymania. Informuje także kobietę (Rosjankę ${ }^{11}$ ) o losach zaginionego męża i wskazuje miejsce pod dużym drzewem w ogrodzie, gdzie zakopał pieniądze. W innym epizodzie widzi i opisuje miejsce przetrzymywania uprowadzonego przez bandytów Hasana. Potrafi również przewidywać przyszłość.

Jasnowidzenie było często związane ze zdolnościami szamańskimi w tradycyjnym szamanizmie, bywa spotykane także u współczesnych baqsï (nie wszystkich - tylko niektórzy otrzymują ten dar od duchów) i innych uzdrowicieli.

Charakterystyczną cechą baqsï jest umiejętność wprowadzania się w trans w tym stanie przywołują duchy i uzdrawiają z ich pomocą. Tę niezwykłą zdolność posiada też filmowa Ayday, co zostało ukazane w filmie dwukrotnie. Są to bardzo ważne sceny, kluczowe dla akcji. W pierwszej Apa unika aresztowania przez policjanta (nasłanego przez biznesmenów-gangsterów), wprowadzając się w stan transu. Stosuje przy tym metody charakterystyczne dla sufich - szybki ruch obrotowy, specyficzny śpiew modlitewny. W rezultacie pada jak martwa i zostaje uznana za zmarłą. Jej ciało zostaje zawiezione do kostnicy, gdzie leży przez jakiś czas w stanie letargu, bez pulsu. Następnie, w nocy, ożywa, opuszcza kostnicę i ukrywa się daleko od domu, pozwalając wszystkim uważać się za zmarłą (ujawnia się jedynie małemu Hasanowi). Tego rodzaju stan letargu często występował u tradycyjnego kazachskiego szamana w trakcie inicjacji. Także współcześnie można usłyszeć relacje szamanów i innych uzdrowicieli o podobnych epizodach „choroby szamańskiej” poprzedzających rozpoczęcie działalności uzdrowicielskiej (traumatyczne przejścia, szok, paraliż, śpiączka).

W drugiej ze wspomnianych scen baqsï odbywa seans uzdrowicielski, starając się, z dobrym skutkiem, wyleczyć Hasana, który „utracił duszę”. Obrzęd uzdrawiania, kończący wcześniejsze, długotrwałe procedury lecznicze (między innymi opisane wyżej smarowanie chłopca krwią zwierzęcą czy zawijanie w skórę), za-

${ }^{11}$ Filmową baqsï odwiedzają nie tylko Kazachowie; przybywają do niej licznie także chorzy innych narodowości. Podobnie, klientelę uzdrowicieli miejskich w Kazachstanie czy Kirgistanie stanowią pacjenci o różnym pochodzeniu etnicznym. 
wiera modlitwy do Allaha, śpiewane na sposób suficki, okrzyki, taniec Apy wokół chorego i specjalne, ekspresyjne gesty i zaklęcia, a odbywa się na szczycie wzgórza, przy wetkniętym w ziemię słupie (co ma wyraźne odniesienia do tradycyjnej kosmologii szamańskiej). Wątki związane $\mathrm{z}$ sufizmem zostały zaznaczone zapewne dlatego, że - jak wiadomo z przekazów etnograficznych - tradycyjny szamanizm kazachski był silnie przeniknięty elementami sufizmu (Garrone 2000: 248; Penkala-Gawęcka 2006: 81-82).

\section{Idee i wartości kazachskiej kultury reprezentowane przez baqsï Ayday}

Do wartości kazachskiej kultury przekazywanych przez postać baqsï w filmie należy wspominana już wyżej szczególna cześć oddawana duchom przodków, przekonanie o ich ścisłej więzi ze światem żywych oraz możliwości uzyskania od nich pomocy i opieki. $Z$ tym łączy się również przywiązanie do ziemi przodków, uznanie jej za świętość.

Wzburzona Ayday nie chce przyjąć oferty kupna ziemi przez obcych - biznesmenów „spod ciemnej gwiazdy”. Wykrzykuje, że „to ziemia święta”, „ziemia przodków”. Ona może uzdrawiać chorych tylko tutaj, bo „w tej ziemi jest jej siła”. Troszczy się o losy licznie przybywających tu ludzi potrzebujących pomocy. Wielu z nich pozostaje na dłużej w gospodarstwie szamanki, mieszka tu i pomaga w różnych pracach. Apa pyta: „Do kogo pójdą ci ludzie?”.

W filmie zaakcentowano traktowanie przez szamankę leczenia jako misji, powinności; jej bezinteresowność. Baqsï nie dba o dobra materialne, otrzymane dary - głównie odzież - rozdaje pacjentom. Taka postawa jest w pełni zgodna z modelem tradycyjnego uzdrowiciela, który nie powinien zabiegać o pomyślność na ziemi, wiedząc, że za czynione dobro będzie wynagrodzony po śmierci.

Tradycyjne normy i wartości pokazane są także nie wprost - wyraża je przeciwstawienie się przez szamankę nałogom niszczącym ludzi fizycznie i duchowo, zachłanności, kultowi pieniądza, rozpuście, czyli łamaniu tradycyjnych zasad życia społecznego. Przedstawiają to doskonale sceny z życia małej społeczności w „wiosce uzdrowicielskiej Ayday”, zwłaszcza te związane z procesem uzdrawiania. Należy podkreślić, że uzdrowienie nie polega tu jedynie na wyleczeniu ciała z choroby. Chodzi przede wszystkim o duchowe uzdrowienie, „oczyszczenie” rozumiane jako odrzucenie zła i zepsucia niesionego przez nowoczesność, powrót do tradycyjnych wartości, przywrócenie tego, co tradycyjnie uważane było za synonim „kazachskości” (qazaqiylïq).

Do eksponujących taką postawę scen należy ta, w której kobieta - Kazaszka prosi, by szamanka pomogła jej chorej córce Gauhar. Apa zgadza się pomóc, każe matce pozostawić Gauhar u niej, ale z obrzydzeniem odrzuca ofiarowane pieniądze. Jak można sądzić, czyni tak przede wszystkim dlatego, że kobieta odeszła od 
tradycyjnych wartości. Ayday mówi, że wie, co spowodowało chorobę córki - to mianowicie, iż matka „nie chciała jej rodzić”.

Szczególnie ostrym kontrastem dla obrazu tradycyjnych norm i wartości propagowanych i wpajanych przez baqsï pacjentom, którzy nieraz daleko od nich odeszli, są sceny z życia biznesmenów-gangsterów. Pokazują one ich kult pieniądza, bezwzględność, brak skrupułów („wszystko można”, „każdego zmusimy”), wiarę, że za pieniądze można kupić wszystko, drwiący, pogardliwy stosunek do kazachskich tradycji. Ci „nowi Kazachowie” nie wierzą w zdolności szamanki; jeden $z$ nich, ostrzegany, że może być ona niebezpieczna, szyderczo odpowiada: „baksy - szmaksy”.

Jedyny związek tak pokazanych „antybohaterów” z tradycją kazachską to głowa barana ${ }^{12}$ wniesiona przez kelnera na tacy podczas suto zakrapianego alkoholem bankietu wydanego dla uczczenia otwarcia stacji benzynowej i restauracji, postawionych na ziemi szamanki, oraz - co robi wrażenie jawnego szyderstwa - muzułmański różaniec w ręku gangstera.

Wzorzec życia tych jednowymiarowych „czarnych charakterów” przegrywa w filmie. Spełnia się, dosłownie, przepowiednia szamanki, że „ziemia pod ich nogami będzie się paliła". Płonie ich stacja benzynowa, a następnie, $w$ dalszym ciągu fabuły, która nabiera cech charakterystycznych dla filmu kryminalnego, przypłacają oni swe zbrodnicze czyny życiem. Tradycyjne wartości kazachskiej kultury zwyciężają z chciwością i konsumpcjonizmem, niosącym zło i degenerację.

\section{Szamanka Bifatima Dauletova - pierwowzór filmowej Ayday}

Filmowa postać inspirowana była życiem i działalnością autentycznej uzdrowicielki-szamanki, która podobno zaakceptowała scenariusz i wyraziła zgodę na kręcenie filmu. Bifatima Apa pozwoliła także ekipie filmowej na przebywanie we wsi i obserwowanie jej sposobów uzdrawiania.

\section{Miejsce seansów leczniczych Bifatimy - „kompleks uzdrowicielski Ungurtas"}

Baqsï Bifatima Dauletova mieszka w wiosce Ungurtas (Üngirtas) („Kamienna pieczara") położonej około $80 \mathrm{~km}$ na zachód od Ałmaty. Jej siedzibę i sposoby

12 Tradycja ceremonialnego, zgodnego ze ścisłymi regułami pierwszeństwa, dzielenia głowy barana podczas szczególnie ważnych uroczystości jest nadal żywa w Kazachstanie i Kirgistanie. 
leczenia opisała Zuzanna Grzywacz ${ }^{13}$, która odwiedziła to miejsce podczas badań prowadzonych w Kazachstanie w latach 2008-2009. O Bifatimie wspominał również Jessa (2009: 77-78, 243-247), a inne informacje i krótki wywiad z nią można znaleźć w wydanej w Ałmaty książeczce, która szczegółowo opisuje Ungurtas jako niezwykłe, święte miejsce odwiedzane przez wielu pielgrzymów. Autorki tego opracowania twierdzą wręcz, że Ungurtas ma obecnie nieoficjalny status „duchowo-uzdrowicielskiego kurortu" (Bilâlova, Ivleva, Sultanova 2007: 14).

Bifatima Apa jest opiekunką (širaqšì) tego miejsca, a przybyła tu podobno w połowie lat 90., wypełniając wskazówki otrzymane od duchów w wieszczym śnie ${ }^{14}$. Jej dom położony jest na skraju wsi, nieopodal cmentarza. Naprzeciw domu wznosi się góra Aydarlï Aydahar Ata, na której szczycie w 2000 roku ustawiono kamienny blok symbolizujący flagę, stanowiący jakoby „centrum strumienia energetycznego wysyłanego z Kosmosu do wnętrza Ziemi” (Jessa 2009: 77) ${ }^{15}$. Tu znajduje się miejsce określane jako „Pępek Ziemi”. O samym świętym Aydahar Ata można usłyszeć różne informacje; Jessa (2009: 244) zauważa, że jest to „nie do końca czytelna postać". Dodaje również, że trudno określić dokładnie liczbę punktów mających znaczenie w leczeniu, bowiem „co jakiś czas «odkrywane» są nowe miejsca w obrębie góry, jak i jej pobliżu” (Jessa 2009: 243). Niewątpliwie ważną częścią procesu uzdrawiania jest wchodzenie na tę świętą górę, gdzie w pieczarach podobno niegdyś mieszkali derwisze czy - jak mówi sama Apa „Wszyscy prorocy” (Bilâlova, Ivleva, Sultanova 2007: 21), dotykanie poszczególnych kamieni (bądź przywieranie do nich ciałem), przepełzanie przez szczeliny skalne i tym podobne metody uzdrawiania, znane także z tradycji innych rejonów Azji Środkowej. Również zastosowane w tym miejscu sposoby odstraszania złych duchów mają swoje paralele w innych częściach Azji Środkowej - gdzieniegdzie powbijano w ziemię drewniane kije obwiązane skrawkami tkanin, a na bramie przed domem umieszczono czaszkę zwierzęcą.

Grzywacz tak opisuje grotę skalną stanowiącą ważną część kompleksu:

Miejsce określane jako „świątynia” znajduje się w podziemnej grocie. Niewielka część przedsionka przeznaczona jest dla chorych, którzy muszą leczyć się w Üngirtas dłużej niż jeden dzień. (...) Dalsza część świątyni udekorowana jest obrazami, które maluje Bifatima, zdjęciami z odwiedzanych mauzoleów, wycinkami z gazet dotyczącymi jej osoby oraz atrybutami muzułmańskimi. Bogate w symbole astrologiczne malunki przedstawiają świat podzielony na trzy po-

13 Wówczas studentka w Instytucie Orientalistyki UAM w Poznaniu; w 2009 r. obroniła pracę magisterską pt. „Tradycyjna medycyna kazachska i uzdrowiciele we współczesnym Kazachstanie” przygotowaną pod moim kierunkiem. Praca ta została opublikowana w języku angielskim (Grzywacz 2010a). Zob. też Grzywacz 2010b.

${ }^{14}$ Ten wątek pojawił się także, w bardzo rozbudowanej postaci, w opowieści mojej znajomej szamanki Rahilyam.

${ }^{15}$ Autor wskazuje na odniesienia przedstawień dotyczących „świętej góry” do idei New Age i dodaje, że niezwykłe zjawiska występujące w Ungurtas potwierdził jakoby w trakcie swoich badań w 2000 r. „akademik”, doktor filozofii z Rosji, V.M. Bronnikov. Na ten temat piszą także Bilâlova, Ivleva, Sultanova (2007: 14). 
ziomy; częsty motyw stanowią zwierzęta. Niedaleko wyjścia leży tekturowe pudełko z napisem sadaqa - jałmużna [przeznaczone na datki - D.P.G.] (Grzywacz 2010b: 77).

\section{Sposoby uzdrawiania, jasnowidzenie, uprawomocnienie Bifatimy}

Wstępnym warunkiem przeprowadzenia leczenia jest rytualna ablucja (daret), przybycie w czystej odzieży (zakrywającej ciało; kobiety obowiązuje także założenie chustki, a mężczyzn - muzułmańskiej czapeczki) i z czystymi zamysłami. Nie wolno odmówić wspólnego wypicia herbaty i zjedzenia specjalnie przygotowanego, przyniesionego z sobą posiłku. Po tym poczęstunku Bifatima Apa udziela obecnym błogosławieństwa (bata), które jest ważnym elementem wieńczącym poszczególne etapy uzdrawiania (Bilâlova, Ivleva, Sultanova 2007: 15-16). Grzywacz zaobserwowała, że szamanka używa wody do rytualnego oczyszczenia pielgrzymów, którzy przybywają do niej i chcą odwiedzić świętą górę w Ungurtas. Oblewa ich wodą, obficie chlustając - nieraz wprost z wiadra (Grzywacz 2010b: $77)^{16}$. Apa jest ponadto szeroko znana ze swej zdolności jasnowidzenia. Autorki opracowania o „kompleksie uzdrowicielskim Ungurtas” przytaczają przykład kobiety - Kazaszki, która chciała wejść na świętą górę, ale širaqšï przegnała ją, wykrzykując głośno: „Bezwstydnica! Przyjechałaś tu, by rzucić czary na cudzego mężczyznę! Dlaczego chcesz zniszczyć cudzą rodzinę?! Kradniesz męża i ojca dzieciom!" (Bilâlova, Ivleva, Sultanova 2007: 22) ${ }^{17}$.

Można rzec, że właśnie w obronie tradycyjnego porządku, wartości tradycyjnej kultury Bifatima zachowuje się nieraz bardzo gwałtownie, napomina przybyłych w ostrych słowach. Jest niewątpliwie charyzmatyczną osobowością. Według Grzywacz (2010b: 77): „Często bije chorych, krzyczy, sprawia wrażenie osoby bardzo silnej, impulsywnej i nieprzewidywalnej, ale również dużo żartuje”. Takie zachowanie jest zresztą zgodne z tradycyjnym sposobem traktowania pacjentów w czasie seansu szamańskiego. Do procedur leczniczych stosowanych przez szamankę należy między innymi polewanie chorych krwią świeżo zabitego barana, bicie płucami zwierzęcymi oraz zawijanie w jeszcze gorącą, dopiero co zdjętą baranią skórę ${ }^{18}$.

${ }^{16}$ Jak podają Bilâlova, Ivleva, Sultanova (2007: 15), Bifatima Apa rytuał ten stosuje wtedy, gdy „Góra nie wpuszcza” - przybywający, którzy chcą wspiąć się na wzgórze, nie są przygotowani duchowo i odczuwają różne dolegliwości, takie jak ból głowy czy duszności.

${ }^{17}$ Należy wyjaśnić, że do uzdrowicieli w Kazachstanie często zwracają się kobiety, które proszą o odprawienie specjalnych czarów (nazywanych często rosyjskim terminem privorot), by pozyskać względy upatrzonego mężczyzny. Jednak część uzdrowicieli - ci, którzy określają się jako „biali”, „Czyści”, w przeciwieństwie do „czarnych” - odmawia, a przynajmniej tak twierdzą, z oburzeniem opowiadając o innych, którzy się tym zajmują.

${ }^{18}$ Takiego chorego, zawiniętego w skórę i leżącego przez całą dobę w przedsionku podziemnej groty, zaobserwowała Grzywacz. 
Podczas seansów syn i pomocnik Bifatimy Serik Tastanov gra na kazachskim instrumencie smyczkowym - qobïz, który był w przeszłości tradycyjnym atrybutem szamańskim pomagającym baqsï w przywoływaniu duchów. Ważne miejsce $\mathrm{w}$ procesie uzdrawiania zajmuje wejście chorych, w towarzystwie szamanki, na górę Aydarlï Aydahar Ata i odbycie tam stosownych rytuałów. Należy dodać, że choć większość metod uzdrowicielskich Bifatimy jest zakorzeniona w tradycji, to jednak potwierdza ona swym autorytetem także nowe wyjaśnienia oddziaływania leczniczego poszczególnych miejsc na górze - takie, które wywodzą się z rozpowszechnionych współcześnie koncepcji „energetycznych”. Przykładowo, przywierając plecami do pionowo stojącego bloku skalnego, człowiek podobno doznaje przepływu przez nerki „strumienia energetycznego” pochodzącego z wnętrza kamienia (Bilâlova, Ivleva, Sultanova 2007: 18). Tego rodzaju przekonania można uznać za spuściznę po działalności tak zwanych ekstrasensów, jakoby zdolnych przekazywać leczniczą energię, popularnych na obszarze ZSRR w latach 80. Współcześni uzdrowiciele, także ci stosujący „tradycyjne” metody, często włączają do swych praktyk elementy takie, jak oddziaływanie energii czy „bioprądów”.

Apa opiera się w swojej działalności na legitymizacji tradycyjnej. Określana jest jako baqsï, ale często także jako „derwisz” i šayh (opiekun miejsca świętego), i sama też tak się nazywa. Pisze się o niej również jako o „sufim” („ostatni sufi Kazachstanu") - to ona właśnie miała, jak się uważa, przechować tradycje sufic$\mathrm{kie}^{19}$. W istocie jednak kazachski derwisz - duwana nie miał żadnych odniesień do bractw sufickich i ich nauk. Pisze o tym Jessa, dodając: „Proces wstępowania na ścieżkę diūāna (inicjacja), jak i jego funkcje tożsame są natomiast z kazachskim baqsi" (Jessa 2009: 78). Tradycyjne uprawomocnienie praktyk Bifatimy dodatkowo wzmacnia odbycie przez nią pielgrzymki do Mekki i Medyny ${ }^{20}$. Formalne uwierzytelnienie nie wydaje się dla niej ważne. Nie posiada certyfikatu i licencji upoważniającej do leczenia; mimo obowiązującego zakazu prawnego prowadziła także zbiorowe seanse uzdrowicielskie (Grzywacz 2010b: 77).

O popularności szamanki świadczą liczne wpisy w internecie, na rozmaitych blogach czy portalach społecznościowych kazachskich i rosyjskich. Według zamieszczonych tam informacji do Bifatimy przybywa kilkaset osób dziennie, są wśród nich także odwiedzający spoza Kazachstanu ${ }^{21}$. Również Grzywacz (2010a: 47) poświadcza, że w trakcie jej pobytu w Ungurtas przybywali tam liczni pielgrzymi. Są takie osoby, które pozostają u boku Apy przez dłuższy czas, zwykle kilka miesięcy, albo przyjeżdżają wielokrotnie i w trakcie pobytu zajmują się róż-

${ }^{19}$ Odniesienia do sufizmu należy traktować raczej jako element kreowanego medialnego wizerunku Bifatimy (o tym więcej w rozważaniach końcowych).

${ }^{20} \mathrm{~W}$ rozmowie z autorkami książki Bifatima podkreślała, że odwiedziła już 800 świętych miejsc. Dodała: „Świętych należy szanować” (Bilâlova, Ivleva, Sultanova 2007: 21).

${ }^{21} \mathrm{~W}$ internecie można znaleźć, oprócz wpisów i fotografii, również amatorskie filmiki pokazujące Ungurtas i szamankę: https://yandex.ru/video/search?text=\%D0\%A3\%D0\%BD\%D0\% B3\%D1\%83\%D1\%80\%D1\%82\%D0\%B0\%D1\%81\&where=all\&where=all (dostęp 05.05.2017). 
nymi pracami w gospodarstwie szamanki, która utworzyła coś w rodzaju „komuny leczniczej"22.

\section{Ayday/Bifatima a szamani miejscy - przykład Rahilyam}

Ayday, jak i jej pierwowzór, Bifatima, to szamanka wiejska, uważana za nosicielkę kazachskich tradycji, która jako część swej misji postrzega ożywianie w dużej mierze zapomnianych wartości przodków. Inaczej prezentują się szaman czy szamanka mieszkający w mieście, zmuszeni do dostosowania się do wymogów środowiska odmiennego od tradycyjnego. Uzdrowiciele z wiosek - aułów zwykle leczą, nie troszcząc się o oficjalnie obowiązujące certyfikaty i licencje, czasem też mogą mieć z tego powodu kłopoty ${ }^{23}$. Podobnie baqsï z filmu nie interesowały te formalne obligacje; $z$ oburzeniem pytała policjanta żądającego od niej okazania „zezwolenia na leczenie”: „kto powiedział, że trzeba jakiegoś zezwolenia, by pomagać ludziom?". Natomiast ich miejscy koledzy często poddają się wszystkim niezbędnym procedurom, by uzyskać stosowne dokumenty. Mimo że w drugiej połowie lat 90. tradycyjna legitymizacja uzdrowicieli nadal stawiana była - zarówno przez pacjentów, jak i samych uzdrowicieli - na pierwszym miejscu, przed nową, biurokratyczną ${ }^{24}$, to jednak ta ostatnia pozwalała im praktykować legalnie i zatrudniać się w rozmaitych centrach medycyny komplementarnej, których wiele powstawało w Ałmaty w owym czasie.

Możliwość zatrudnienia w oficjalnie działającej placówce i stałego zarobku łączyła się jednak z koniecznością komercjalizacji działań, rywalizacji o pacjentów i poszerzania oferty leczniczej o nowe, nietradycyjne metody. Dotyczyło to różnych kategorii uzdrowicieli - w znacznym stopniu także tych, których można uważać za szamanów ${ }^{25}$. Niejednokrotnie moi rozmówcy - uzdrowiciele narzekali, że muszą pobierać opłatę za leczenie według wyznaczonych przez kierownictwo danego ośrodka stawek. Ci, którzy mieli tak dobrą pozycję, że mogli pracować samodzielnie, często różnicowali stosunek do chorych, nie biorąc wynagrodzenia od najbiedniejszych i przyjmując chętnie zamiast pieniędzy dary w naturze. Ry-

${ }^{22}$ Zob. np. http://www.prokopchik.com/apashka/\#description (dostęp 03.05.2017); https://birdinflight.com/inspiration/project/washed-blood-guest-shaman-bifatima.html (dostęp: 25.05.2017). Podobną wioskę - „komunę uzdrowicielską” zorganizowała koło Pawłodaru, na północy Kazachstanu, słynna uzdrowicielka Umut Apa (Penkala-Gawęcka 2006: 205).

${ }^{23}$ Procedury zdobywania owych certyfikatów i licencji były długotrwałe i kosztowne. Przez długi czas przymykano oko na brak stosownych dokumentów, jednak w 1997 r. w Centrum powstał specjalny oddział rewizyjny i zaczęto przeprowadzać częstsze weryfikacje uzdrowicieli, także na prowincji (Penkala-Gawęcka, 2006: 187-190).

${ }^{24}$ Rozróżnienie na legitymizację tradycyjną i biurokratyczną stosuję za Galiną Lindquist (2001), która wyróżniła ponadto legitymizację charyzmatyczną i „poprzez obcość”.

${ }^{25}$ Czyli tych, którzy uzdrawiają, wprowadzając się w trans i w tym stanie wzywając na pomoc duchy; są oni obdarzeni szczególną charyzmą i w opinii społecznej uznawani za baqsï. 
walizacja o pacjentów przejawiała się w różnych sposobach reklamowania własnych umiejętności, a czasem także w próbach zdyskredytowania konkurentów, na przykład poprzez oskarżenia o czarną magię. Wśród nowych metod natomiast, których dołączenie pomagało zdobywać pacjentów w środowisku miejskim, najchętniej stosowane były „bioprądy” i podobne formy oddziaływania energią.

Przykładem miejskiej uzdrowicielki może być ujgurska szamanka mieszkająca w Ałmaty (a później w okolicznej wiosce), Rahilyam ${ }^{26}$. Jej droga do działalności uzdrowicielskiej przebiegała według tradycyjnego wzorca, w którym zasadniczą rolę odgrywała „choroba szamańska”, długi proces przygotowań i doskonalenia, oczyszczania i zdobywania duchów opiekuńczych, wreszcie - błogosławieństwo (bata) doświadczonych uzdrowicieli sankcjonujących dalszą samodzielną pracę nowej szamanki i przekazujących ją pod opiekę części własnych duchów-pomocników ${ }^{27}$. Niemniej szamanka (ujg. baxšï) Rahilyam poddała się później także nowej, biurokratycznej legitymizacji w Centrum Medycyny Wschodniej i Nowoczesnej w Ałmaty, co pozwoliło jej podejmować pracę w różnych ośrodkach medycyny komplementarnej. Wyrażała jednak żal z powodu kontaktów z Centrum (które nazwała „matecznikiem czarnej magii”!), twierdząc, iż duchy powstrzymywały ją od tego, a sprzeciwienie się ich woli opóźniło jej dalszy rozwój duchowy.

W okresie gdy odwiedzałam ją w mieście, Rahilyam przyjmowała pacjentów $\mathrm{w}$ jednym z miejskich, przyszpitalnych centrów medycyny komplementarnej, gdzie przychodzili nie tylko muzułmanie - Kazachowie, Tatarzy czy Ujgurzy, ale także Rosjanie, Ukraińcy, Białorusini, Niemcy czy Koreańczycy. Szamanka, uważając się za muzułmankę, starała się pozyskać jako swe duchy opiekuńcze i pomocnicze także bogów i świętych innych religiii ${ }^{28}$. Twierdziła, że jej „rodzimi” pomocnicy - duchy przodków oraz świętych muzułmańskich - nie są w stanie wyleczyć ludzi innych religii.

Rahilyam przyjmowała też prywatnie i w tym celu urządziła specjalną „przychodnię" obok swojego domu w pobliżu Ałmaty. Miejsce to było pełne przedmiotów związanych z różnymi religiami. Obok obiektów i atrybutów muzułmańskich, takich jak przedstawienia Kaaby czy zawieszone na ścianie różańce muzułmańskie (täspi), widniały tam wizerunki między innymi Chrystusa, Maryi, Buddy, bóstw hinduizmu oraz współczesnego indyjskiego guru Sai Baby, który także stał się jednym z „opiekunów duchowych” Rahilyam. Jednocześnie tradycyjne wzorce przejawiały się wyraźnie nie tylko w inicjacji baxšĭ, ale także w okolicznościach pozyskiwania kolejnych duchów opiekuńczych (w trakcie pielgrzymek do miejsc

${ }^{26}$ Ujgurskie praktyki szamańskie i związane z nimi wyobrażenia są bardzo zbliżone do kazachskich.

27 Ten proces, który może być traktowany jako wręcz „wzorcowy” przykład obrzędu przejścia, opisałam dokładnie w innym miejscu (Penkala-Gawęcka 2001). Zob. też opis tradycyjnej inicjacji współczesnego kazachskiego szamana w artykule Jessy (2001: 196-199).

${ }^{28}$ Wymieniała ponadto postaci, które znała z filmów - jak zmarły hinduski tancerz, aktor z Bollywood czy japońscy karatecy. 
świętych) czy sposobach leczenia - z wprowadzaniem się w stan transowy i wzywaniem duchów, które miały uzdrawiać pacjentów za jej pośrednictwem. Ten eklektyzm był uderzający w praktyce szamanki, a Rahilyam nie kryła, że taka postawa pomaga jej poszerzać krąg pacjentów. Wierzyła ponadto, iż doskonaląc się, dojdzie do wyższego „szczebla duchowego" i zyska kiedyś uznanie w świecie ${ }^{29}$.

Choć Rahilyam była wyjątkowa w swych szerokich, niemal globalnych poszukiwaniach, to hybrydyzacja praktyk leczniczych, wzbogacanie tradycyjnych metod o różne elementy obce, nowe, w celu pozyskania większej liczby pacjentów, są niewątpliwie bardzo charakterystyczne dla współczesnych uzdrowicieli miejskich $^{30}$. Taki kierunek dalszego rozwoju praktyk uzdrowicielskich w Kazachstanie poświadcza też w swoich opracowaniach Grzywacz (2010a: 46-47), wskazując na rosnące możliwości dokształcania uzdrowicieli, między innymi w ramach różnorodnych kursów prowadzonych przez ich stowarzyszenia.

\section{Zakończenie}

Nie można wprawdzie uznać filmu Baksy za „opowieść narodową” (national narrative) opowiadającą o początkach, męczeństwie i chwale narodu - jak nazwał tego rodzaju narracje Ronald Suny (2001: 866), czy też za przykład nowego gatunku filmowego, który Laruelle (2015) określiła jako „rozrywkę patriotyczną” (patriotic entertainment). Przekazuje on jednak wiele wartości uznanych za wyróżniające dla kazachskiej tożsamości narodowej. Tę kazachskość „W pigułce”, szczególnie przywiązanie do dziedzictwa przodków, reprezentuje bohaterka, Ayday Apa.

Nie było moim celem przeanalizowanie, czy obraz baqsï $\mathrm{w}$ filmie $\mathrm{w}$ pełni odpowiada cechom i działalności szamanki Bifatimy, która zainspirowała twórców. Sądzę jednak, że ich intencją było ukazanie właśnie takiej postaci, która oddawałaby cechy tradycyjnej figury baqsï i która obrazowałaby „kazachskość” - to, co uważa się za jądro, zestaw podstawowych wartości kazachskiej kultury. Przesłaniem filmu Omarovej jest zachęta do powrotu do tych tradycyjnych wartości, przeciwstawionych wszelkim plagom współczesnego świata. Nie mogłaby więc stać się bohaterką filmu niosącego takie przesłanie szamanka miejska, eklektyczna, łącząca tradycję z innowacjami zaczerpniętymi z różnych obcych źródeł, taka jak moja znajoma baxši Rahilyam.

Należy jednak dodać, że nawet jeśli w momencie powstawania filmu Bifatima Dauletova mogła być postrzegana przez jego twórców jako prawdziwie „tradycyjna baqsï", to później zyskała ona nową twarz. Późniejsza, w dużej mierze

${ }^{29}$ Niestety, zmarła kilka lat później, nie osiągając zamierzonych celów.

${ }^{30}$ Hybrydyzację praktyk uzdrowicieli miałam okazję obserwować także podczas późniejszych badań prowadzonych w Biszkeku, stolicy Kirgistanu, w latach 2011-2013. Analogiczne przykłady silnego eklektyzmu w działalności szamanów miejskich mieszkających w Ułan Ude, stolicy Buriacji, podała Caroline Humphrey (2010: 271-280). 
wzmocniona sukcesami obrazu Baksy popularność szamanki świadczy, że i ona w dużym stopniu „otwarła się na świat”. Trudno powiedzieć, w jakiej mierze sama Apa wpłynęła na kreowany przez innych wizerunek „ostatniego derwisza Kazachstanu”. Znalazła się na okładce „Discovery Travel Magazine”, stała się bohaterką sesji fotograficznych i zakrojonych na większą skalę „,wideo- i fotoprojektów”. Najważniejszy z takich projektów, zakończony w 2009 roku dokumentalnym filmem The Last Dervish of Kazakhstan, niewątpliwie dodał sławy Bifatimie, a ona sama odwiedziła Sankt Petersburg, Moskwę i Kijów, uczestnicząc w otwarciu wystaw fotograficznych związanych $\mathrm{z}$ tym przedsięwzięciem ${ }^{31}$. Nie wiadomo, czy te nowe doświadczenia zmieniły praktyki uzdrowicielskie Apy, przypuszczalnie nie mogłaby już jednak pełnić funkcji owej „wzorcowej”, „autentycznej” szamanki, uosobienia prastarych kazachskich tradycji ${ }^{32}$.

\section{Bibliografia}

Akataj S.

2001 Drevnie kul'ty i tradicionnaâ kul'tura kazahskogo naroda, Almaty.

Bilâlova G.N., Ivleva N.V., Sultanova M.Ė.

2007 Sakral'nye mesta Almatinskoj aglomeracii (na primere duhovno-ozdorovitel'nogo kompleksa Ungurtas), Almaty.

Garrone P.

2000 Chamanisme et islam en Asie Centrale. La baksylyk hier et aujourd'hui, Paris.

Grzywacz Z.

2010a Traditional Kazakh Medicine in Change, „Turkic Studies”, 2, Adam Mickiewicz University, Poznań, http://www.turkicstudies.amu.edu.pl/turkic_studies_2_2010.pdf (dostęp 02.05.2017).

Grzywacz Z.

2010b Wspótcześni uzdrowiciele w Kazachstanie - nosiciele tradycji czy konkurenci na rynku ustug medycznych?, w: Nie czas chorować? Zdrowie, choroba i leczenie w perspektywie antropologii medycznej, red. D. Penkala-Gawęcka, Poznań, s. 77-78.

Habieva T.

2004 Ozdorovitel'nye metody narodnoj mediciny Kazahstana - čast' novoj politiki ohrany zdorov'â, w: Materialy. I Meždunarodnyj naučno-teoretičeskij Kongress Narodnaâ medicina Respubliki Kazahstan "prošloe, nastoâ̂ee, buduŝee"(Almaty, 16-18 sentâbrâ 2004 g.), red. Š.M. Šintaev, Z. Kožalymov, Almaty, s. 232-238.

${ }^{31}$ http://www.kazakhdervish.com/about-us.php (dostęp 23.05.2017). Można stwierdzić, że tyleż co sławie baqsï, projekt ten przysłużył się popularności jego twórców, Olesji Bondarevej i Mauri Pasanena, prezentujących się jako uczniowie Bifatimy, którym przekazała ona jakoby część tajników swej „sufickiej” i szamańskiej wiedzy.

${ }^{32}$ Również Ungurtas nie ominął proces komercjalizacji - o tym, że „święta góra” staje się nie tylko coraz częstszym miejscem pielgrzymek, ale i popularnym kierunkiem turystycznych wycieczek, może świadczyć np. seria fotografii zamieszczonych w internecie: http://friends.kz/ mountins/1148095098-poezdka-k-pupu-zemli-v-poselok-ungurtas.html (dostęp 25.05. 2017). 
Humphrey C.

2010 Szamani $w$ mieście, w: C. Humphrey, Koniec radzieckiego życia. Ekonomie życia codziennego po socjalizmie, przeł. A. Halemba, Kęty, s. 271-289.

Jessa P.

2001 Współczesny szaman kazachski. Baksy Ajtkurman, „Lud”, t. 85, s. 193-208. Jessa P.

2009 „Przyjaciele Allaha”. Kult muzułmańskich świętych w Azji Środkowej, Poznań.

Kudaibergenova D.T.,

2017 Punk Shamanism, Revolt and Break-up of Traditional Linkage: The Waves of Cultural Production in Post-Soviet Kazakhstan, „European Journal of Cultural Studies”, First published on-line January 13, 2017 (dostęp 23.05.2017).

Laruelle M.

2007 Religious Revival, Nationalism and the "Invention of Tradition”: Political Tengrism in Central Asia and Kazakhstan, „Central Asian Survey”, t. 26 (2), s. 203-216.

Laruelle $\mathrm{M}$.

2015 In Search of Kazakhness: The Televisual Landscape and Screening of Nation in Kazakhstan, „Demokratizatsiya: The Journal of Post-Soviet Democratization”, t. 23 (3), s. 321-340.

Lindquist $\mathrm{G}$.

2001 The Culture of Charisma: Wielding Legitimacy in Contemporary Russian Healing, „Anthropology Today”, t. 17 (2), s. 3-8.

Penkala-Gawęcka D.

1988 Medycyna tradycyjna w Afganistanie i jej przeobrażenia, Wrocław.

Penkala-Gawęcka D.

2001 Wybrańcy duchów, czyli jak zostać szamanem. Na przykładzie ujgurskiej szamanki $z$ Kazachstanu, „Lud”, t. 85, s. 153-191.

Penkala-Gawęcka D.

2006 Medycyna komplementarna w Kazachstanie. Siła tradycji i presja globalizacji, Poznań.

Penkala-Gawęcka D.

2009 Mikropolityka etniczności. Obchody wiosennego święta Nauryz w postsowieckim Kazachstanie, „Etnografia Polska”, t. 53 (1-2), s. 5-19.

Privratsky B.G.

2001 Muslim Turkistan: Kazak Religion and Collective Memory, Richmond.

Rancier M.

2009 Resurrecting the Nomads: Historical Nostalgia and Modern Nationalism in Contemporary Kazakh Popular Music Videos, „Popular Music and Society”, t. 32 (3), s. 387-405.

Schatz E.

2000 The Politics of Multiple Identities: Lineage and Ethnicity in Kazakhstan, „Europe-Asia Studies", t. 52 (3), s. 489-506.

Suny R.G.

2001 Constructing Primordialism: Old Histories for New Nations, „The Journal of Modern History", t. 73 (4), s. 862-896.

Valihanov Č.,

1986 Izbrannye proizvedeniâ, Moskva. 


\section{Materiały internetowe}

Index Mundi, Kazakhstan Demographics Profile 2016, http://www.indexmundi.com/kazakhstan/demographics_profile.html (dostęp 24.05.2017).

Kazakhdervish.com. A Documentary Film Project, http://www.kazakhdervish.com/about-us.php (dostęp 23.05.2017).

Almatinskie friends.kz, http://friends.kz/mountins/1148095098-poezdka-k-pupu-zemli-v-poselok-ungurtas.html (dostęp 25.05. 2017).

Apashka, http://www.prokopchik.com/apashka/\#description (dostęp 03.05.2017).

Bird in Flight, https://birdinflight.com/inspiration/project/washed-blood-guest-shamanbifatima.html (dostęp 25.05.2017).

https://yandex.ru/video/search?text=\%D0\%A3\%D0\%BD\%D0\%B3\%D1\%83\%D1\%80\%D

$1 \% 82 \% \mathrm{D} 0 \% \mathrm{~B} 0 \% \mathrm{D} 1 \% 81 \& w h e r e=a l l \& w h e r e=a l l($ dostęp 05.05.2017). 


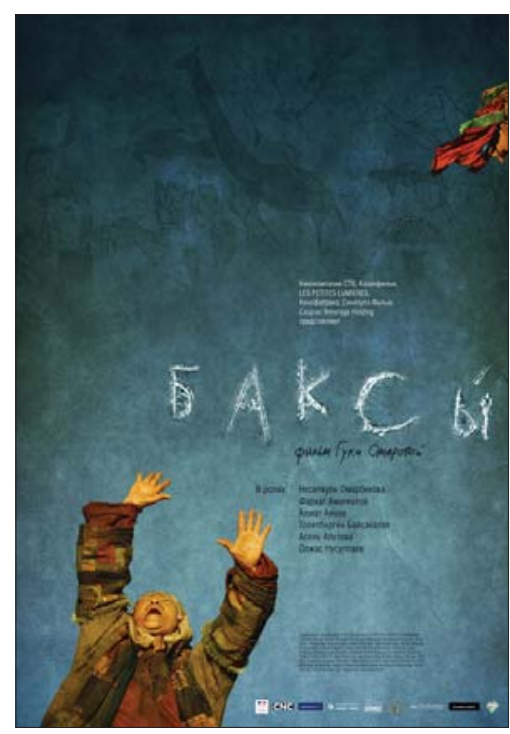

Fot.1. Plakat filmu Baksy (http://ctb.ru/ en/films/native-dancer-baksy/)
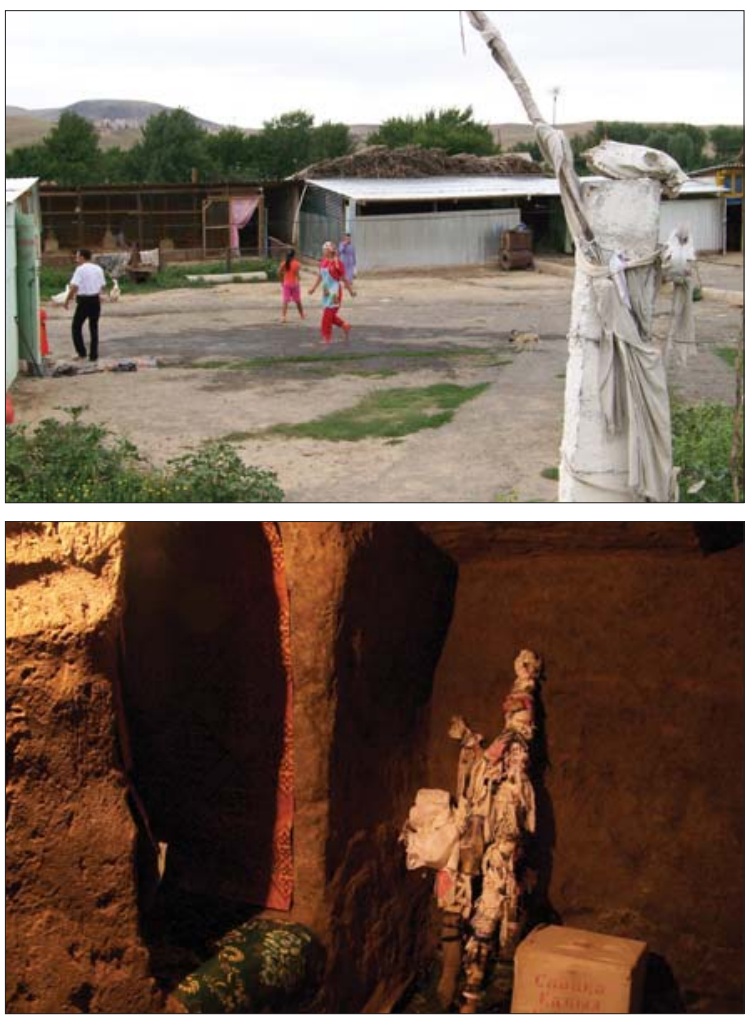

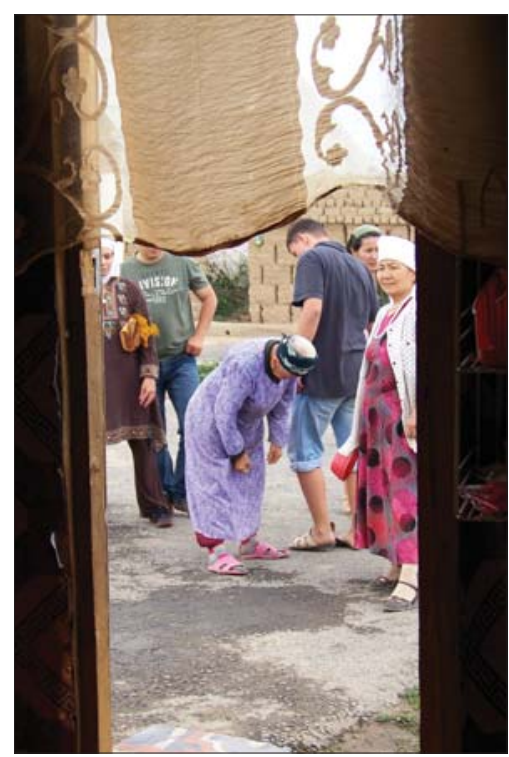

Fot. 2. Szamanka Bifatima (pośrodku, pochylona). Ungurtas.

Fot. Z. Grzywacz, 2008.

Fot. 3. Czaszki zwierzęce u wejścia do domu Bifatimy - dla ochrony przed złymi duchami. Ungurtas. Fot. Z. Grzywacz, 2008.

Fot. 4. Przedmioty rytualne i pudełko na jałmużnę w grocie Bifatimy. Ungurtas.

Fot. Z. Grzywacz, 2008. 


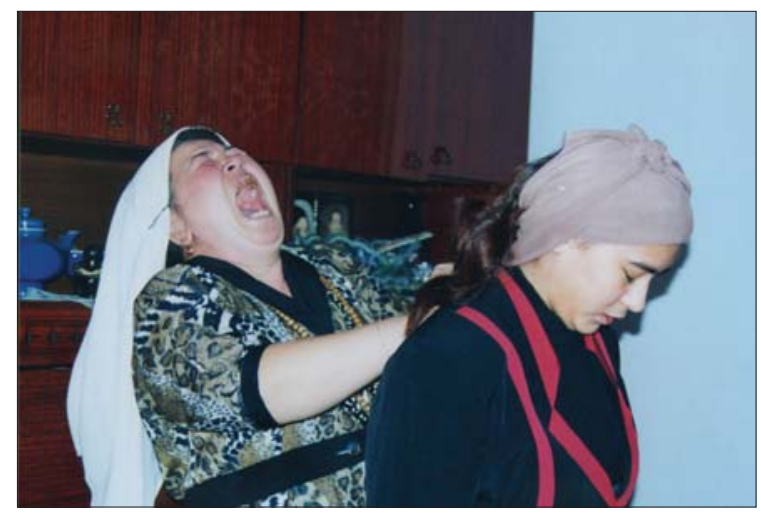

Fot. 5. Szamanka Rahilyam i jej pacjentka podczas seansu leczniczego. Ałmaty, przysiółek Drużba. Fot. D. Penkala-Gawęcka, 1997.

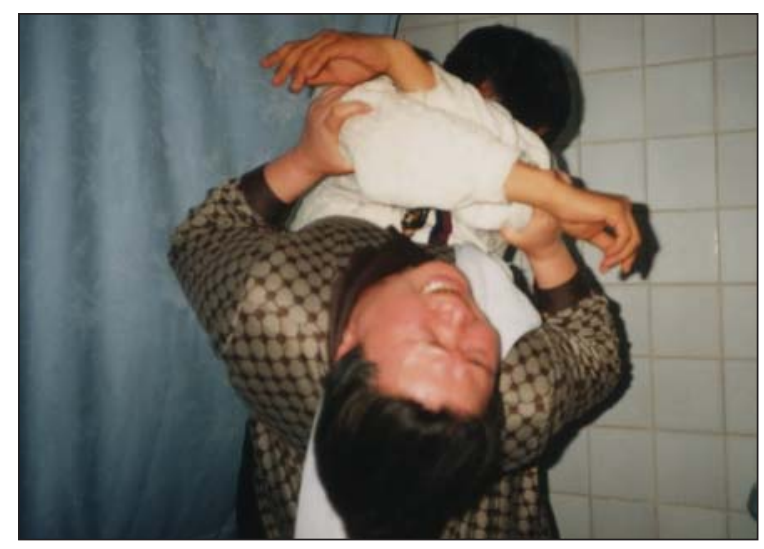

Fot. 6. Seans leczniczy szamanki Rahilyam. Ałmaty. Fot. D. Penkala-Gawęcka, 1998.

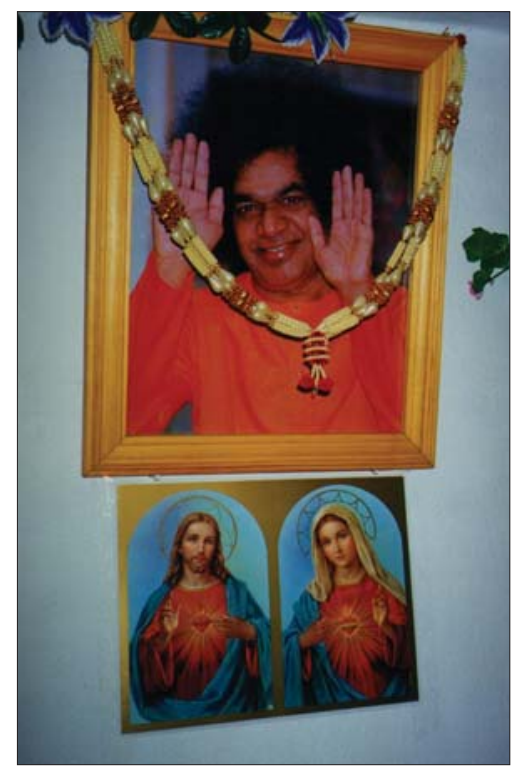

Fot. 7. W „przychodni” Rahilyam obok jej domu - Sai Baba, Jezus i Maryja. Okolice Ałmaty. Fot. D. Penkala-Gawęcka, 2000. 